\title{
PENDEKATAN ANALISIS FISHBONE UNTUK MENGUKUR KINERJA PROSES BISNIS INFORMASI E-KOPERASI
}

\author{
Fikri Hamidy \\ Manajemen Informatika, AMIK Teknokrat, \\ Jl.ZA Pagaralam, No 9-11, Labuhanratu, Bandarlampung, Indonesia \\ Email: fikrihamidy@teknokrat.ac.id
}

\begin{abstract}
Abstrak
Koperasi merupakan badan usaha yang memiliki krakteristik keberpihakan kepada ekonomi kerakyatan. Bulan September Tahun 2015 kegiatan proses bisnis informasi melalui aplikasi manajemen usaha yang terintegrasi telah diluncurkan oleh pemerintah dengan nama e-Koperasi. Penerapan E-Koperasi di seluruh Wilayah Indonesia diharapkan secara positif menghasilkan efesiensi dan transparansi pelaporan keuangan koperasi dapat terwujud segera. Permasalahannya adalah penerapan e-Koperasi memerlukan kesiapan pengguna oleh badan usaha koperasi itu sendiri. Tujuan penelitian ini adalah untuk memberikan masukan berupa hasil analisis kesiapan pengguna dengan pendekatan Fishbone Analysis.
\end{abstract}

Kata kunci: E-koperasi, Analisis Fishbone, Kesiapan

\section{PENDAHULUAN}

Koperasi adalah salah satu badan usaha yang melakukan kegiatan layaknya badan usaha lainnya yaitu Badan Usaha Milik Swasta (BUMS) dan Badan Usaha Milik Negara (BUMN). Koperasi melakukan transaksi dan mengelola data transaksi menjadi informasi keuangan yang dibutuhkan baik pihak internal maupun untuk pihak eksternal.

Karakteristik Koperasi yang dianggap sebagai usaha kerakyatan dengan asas kekeluargaan sangat potensial berperan dalam pembangunan ekonomi kerakyatan. Dalam perkembangannya usaha koperasi mengalami kenaikan pertumbuhan yang signifikan. Menurut data BPS pada tahun 2006-2014 jumlah koperasi di Indonesia mengalami peningkatan yang signifikan sebesar 48,82\%. Dimana pada tahun 2006 sebanyak 98.944 koperasi dan pada tahun 2014 sebanyak 147.249 koperasi dari keseluruhan 34 Propinsi di Indonesia.

Aplikasi Manajemen Usaha Koperasi disebut sebagai e-Koperasi merupakan sistem aplikasi manajemen usaha koperasi yang terintegrasi dan berdampak kepada efisiensi dan transparansi. Aplikasi Manajemen Usaha Koperasi dikhususkan untuk mengelola dua jenis unit usaha koperasi yaitu retail dan simpan pinjam (Kementerian Koperasi dan UKM, 2015).

Peluncuran aplikasi e-Koperasi perlu di apresiasi sebagai usaha untuk melakukan pengendalian internal dalam sistem informasi akuntansi suatu koperasi. Rumusan masalahnya adalah pertama :bagaimana kesiapan pengguna e-koperasi? Kedua: Masalah apa saja yang harus ditangani untuk percepatan penerimaan sistem e-Koperasi? Penelitian ini bertujuan untuk mengukur kinerja proses bisnis informasi e-Koperasi dilihat dari kesiapan pengguna menggunakan analisis Fishbone.

\section{METODE PENELITIAN}

Analisis Fishbone (atau Ishikawa) adalah suatu pendekatan terstruktur yang memungkinkan dilakukan suatu analisis lebih terperinci dalam menemukan penyebab-penyebab suatu masalah, ketidaksesuaian, dan kesenjangan yang ada (Gaspers, V. 2002.)

Langkah-langkah yang harus dilakukan adalah:

1) Pengumpulan data;

2) Menggambarkan bagan faktor penyebab;

3) Identifikasi akar masalah;

4) Rekomendasi dan implementasi.

\subsection{Gambaran e-Koperasi}

\section{HASIL DAN DISKUSI}

Secara umum alur aplikasi E-Koperasi terdiri dari modul simpan pinjam (akuntansi simpan pinjam) dan modul retail (akuntansi retail). Aplikasi adalah versi awal (1.00) memuat 2 modul untuk 2 jenis koperasi (simpan pinjam dan retail/pemasaran) sepertin pada gambar 1. dan gambar 2.

Di Indonesia ada 6 (enam) jenis koperasi yaitu: simpan pinjam, konsumen, produsen, pemasaran, jasa dan serba usaha.

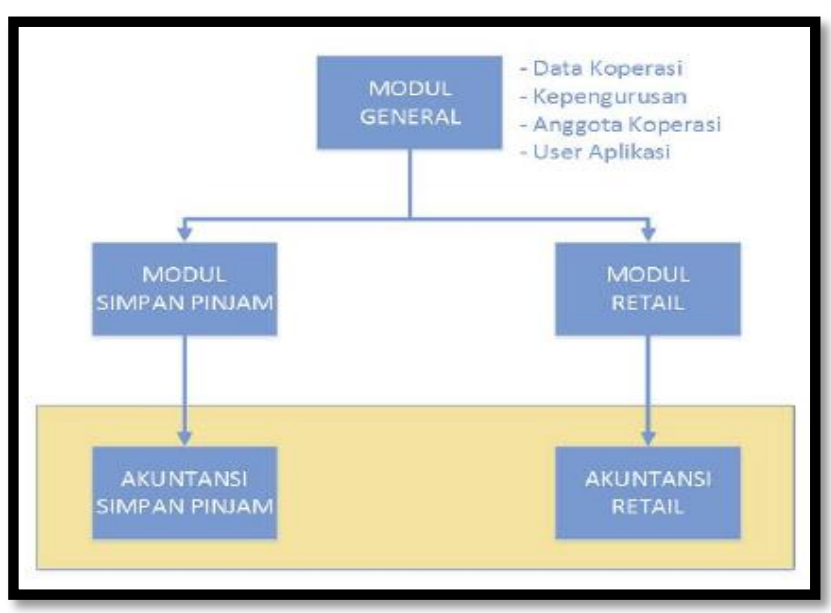

Gambar 1. Alur Aplikasi e-Koperasi 


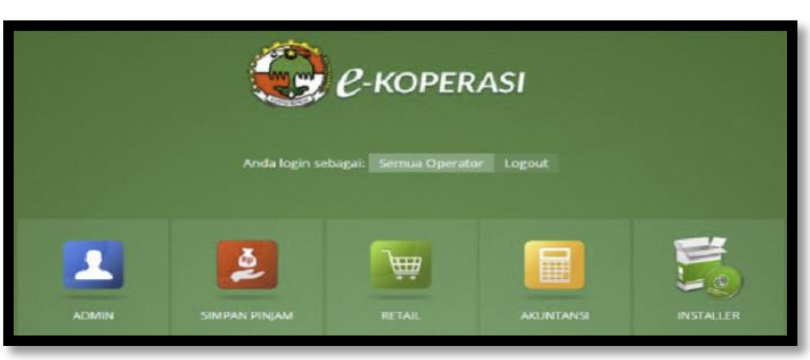

Gambar 2.Tampilan Modul Utama e-Koperasi

\subsection{Survey Koperasi}

Pengumpulan data dilakukan kepada 10 koperasi secara random di Kota Bandarlampung. (6 retail dan 4 simpan pinjam). Sampel random terdiri dari 3 manajer dan 7 staf koperasi.

Survey terhadap koperasi di Bandarlampung menghasilkan hasil survey pada tabel 1 di bawah ini.

\section{Tabel 1. Hasil Survey Kesiapan Pengguna e-Koperasi}

\begin{tabular}{|c|l|c|}
\hline No. & \multicolumn{1}{|c|}{ Butir Pertanyaan } & $\begin{array}{c}\text { Hasil } \\
\text { Survey }\end{array}$ \\
\hline 1. & Perbandingan komputer dan pegawai & $1: 5$ \\
\hline 2. & $\begin{array}{l}\text { Perbandingan kemampuan pegawai } \\
\text { keterampilan TI }\end{array}$ & $1: 14$ \\
\hline 3. & Prosentase ketersediaan komputer & $80 \%$ \\
\hline 4. & Prosentase perawatan komputer & $10 \%$ \\
\hline 5. & $\begin{array}{l}\text { Prosentase keoptimalan SDM } \\
\text { terampil }\end{array}$ & $20 \%$ \\
\hline 6. & Prosentase server sbg. Alat terpadu & $10 \%$ \\
\hline 7. & Prosentase penganggaran perawatan & \\
\hline 8. & komputer & $10 \%$ \\
\hline 9. & Prosentase pemanfaatan e-Koperasi & $20 \%$ \\
\hline 10. & Prosentase pemanfaatan web & $20 \%$ \\
\hline 11. & parsial & Prosentase komputer terintegrasi \\
\hline 12. & $\begin{array}{l}\text { Prosentase operator \& administrator } \\
\text { handal }\end{array}$ & $50 \%$ \\
\hline 13. & Prosentase pemutakhiran dan & $20 \%$ \\
\hline & keakuratan data & $20 \%$ \\
\hline
\end{tabular}

$$
\text { (data diolah : 2016) }
$$

Dari hasil survey dapat diketahui bahwa dari 10 koperasi tidak semua memiliki komputer (80\%). Pemanfaatan komputer sebagai alat bantu proses bisnis belum maksimal. Aplikasi e-Koperasi telah mulai dimanfaatkan oleh $20 \%$ koperasi, sedangkan $80 \%$ lainnya belum menggunakannya. Koperasi sudah mengembangkan aplikasi parsial sebesar 50\%, hal ini akan berpengaruh terhadap penyesuaian sistem lama ke sistem baru. Pengelolaan pemutakhiran data hanya dilakukan oleh $20 \%$ sehingga informasi yang dihasilkan belumlah akurat. Secara prosentase hanya $20 \%$ pengguna yang memiliki kesiapan dalam pemanfaatan e-Koperasi.

\subsection{Analisis Akar Masalah}

Langkah-langkah akar masalah dapat dijabarkan sebagai berikut:

Langkah pertama : Pengumpulan data.

Data dikumpulkan dengan metode survey terhadap 10 (sepuluh) koperasi dengan komposisi 6 retail dan 4 simpan pinjam. Analisis dilakukan dengan metode brain storming.

Langkah kedua :

Membuat gambar faktor-faktor penyebab masalah. Seperti terdapat pada gambar 3. Hasil dari brain storming disimpulkan bahwa penyebab faktor kesenjangan kesiapan pengguna e-Koperasi adalah: komponen hardware, software, brainware (SDM), infrastruktur, data-informasi dan badan usaha.

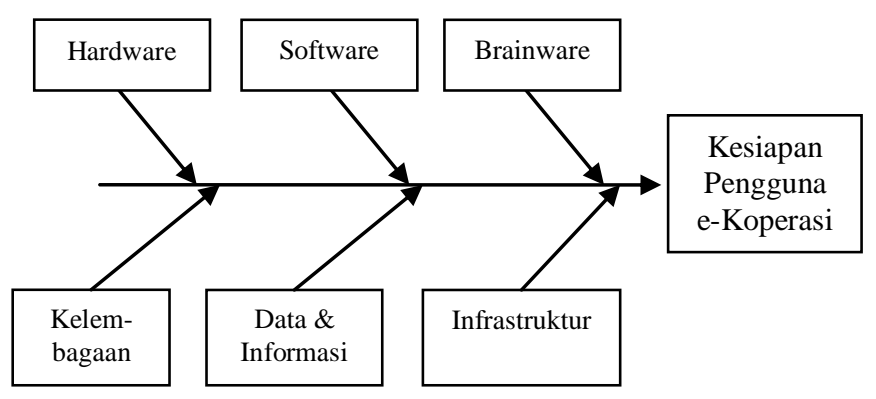

\section{Gambar 3. Diagram Fishbone Kesiapan Pengguna e-Koperasi}

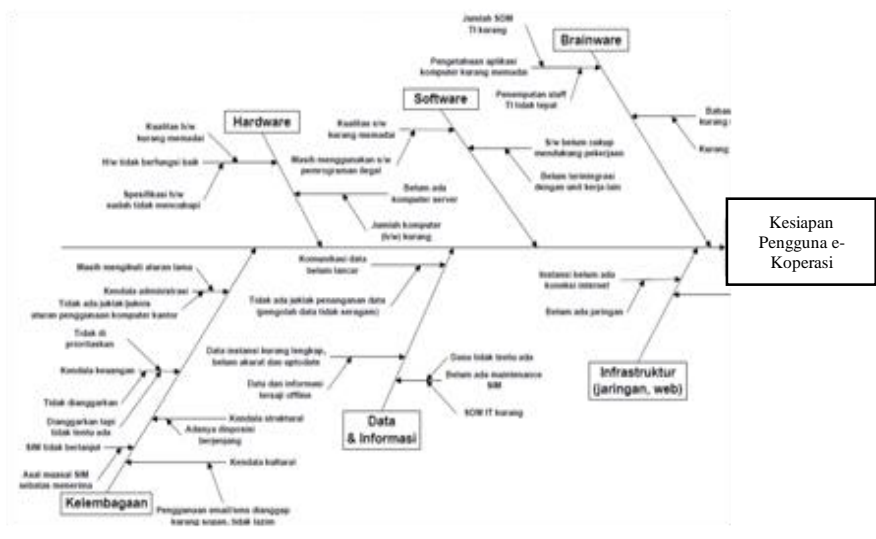

\section{Gambar 3. Diagram Detail Fishbone Kesiapan Pengguna e-Koperasi}

Gejala (simpton) faktor-faktor penyebab kesenjangan kesiapan pengguna e-Koperasi dirumuskan pada tabel 2 berikut ini.

Tabel 2. Gejala Faktor Fishbone

\begin{tabular}{|c|c|l|}
\hline No. & \multicolumn{1}{|c|}{ Faktor } & \multicolumn{1}{c|}{ Gejala } \\
\hline & & $\begin{array}{l}\text { Hardware tidak berfungsi } \\
\text { dengan baik. Kualitas yang } \\
\text { kurang memadai. Spesifikasi }\end{array}$ \\
1. & Hardware &
\end{tabular}




\begin{tabular}{|c|c|c|}
\hline & & $\begin{array}{l}\text { dinilai sduah tidak mencukupi } \\
\text { kebutuhan pengguna. }\end{array}$ \\
\hline 2. & Software & $\begin{array}{l}\text { Kualitas software yang kurang } \\
\text { memadai. Software illegal. } \\
\text { Tidak dilengkapi software } \\
\text { pendukung seperti antivirus } \\
\text { terupdate, OS terintegrasi, }\end{array}$ \\
\hline 3. & Brainware & $\begin{array}{l}\text { Keterampilan IT kurang } \\
\text { memadai karena kurangnya } \\
\text { pelatihan. Pegawai tidak } \\
\text { memiliki latar belakang TI } \\
\text { kurang atau tidak ada. } \\
\text { Keterbatasan penanganan } \\
\text { masalah TIK karena SDM TI } \\
\text { kurang/tidak memadai. }\end{array}$ \\
\hline 4. & Infrastruktur & $\begin{array}{l}\text { Tidak/kurang memadainya } \\
\text { infrastruktur jaringan, C-Server. } \\
\text { Karena tidak ada pengadaaan } \\
\text { atau tidak ada anggaran dana } \\
\text { untuk itu. }\end{array}$ \\
\hline 5. & $\begin{array}{l}\text { Data \& } \\
\text { Informasi }\end{array}$ & $\begin{array}{l}\text { Pengelolaan data tidak ada/ } \\
\text { kurang memadai. Informasi } \\
\text { tidak valid karena data tidak } \\
\text { dikelola dengan baik. }\end{array}$ \\
\hline 6. & Kelembagaan & $\begin{array}{l}\text { Kendala administrasi }=50 \% ; \\
\text { Kendala Keuangan }=80 \% ; \\
\text { Kendala Kultur }=70 \% ; \text { Kendala } \\
\text { Struktural }=70 \%\end{array}$ \\
\hline
\end{tabular}

Langkah ketiga : Mengidentifikasi akar masalah. Akar masalah yang utama dari gejala adalah: kebiasaan (habit), kebutuhan (need), keberlanjutan (sustainable) dan koordinasi.

Kebiasaan yang baik adalah dari contoh atau teladan dari manajer untuk membina dan memotivasi staf koperasi sebagai pengguna e-Koperasi. Kebutuhan akan pelaporan yang informatif mendorong pengguna berusaha memahami sistem yang baru. Keberlanjutan eKoperasi harus dijamin oleh pemerintah dalam hal ini Kementerian Koperasi sehingga keterampilan yang dimiliki semakin meningkat. Kecenderungan aplikasi terbengkalai dan ditinggalkan karena kepentingan sementara. Anggaran atas keberlanjutan sistem diperlukan karena kebutuhan sistem yang dinamis. Koordinasi dalam implementasi bisa mengacu pada panduan bersama dengan Dinas Koperasi Kota dan Propinsi.

Langkah keempat: Rekomendasi dan implementasi.

Rekomendasi yang ditujukan kepada Manajer Koperasi adalah:

1) Membangun habit dan need di lingkungan koperasi. Terjadi iklim yang baik memotivasi pengguna untuk memiliki keterampilan yang memadai terkait sistem informasi menggunakan e-Koperasi;
2) Menyusun arah kebijaksanaan implementasi peningkatan daya saing koperasi menggunakan sistem terintegrasi;

3) Berkoordinasi dengan dinas koperasi tentang implementasi e-Koperasi.

4) Mengajukan penganggaran peningkatan piranti, infrastrktur dan SDM untuk menunjang implementasi e-Koperasi.

\section{KESIMPULAN}

Kesiapan pengguna e-Koperasi dari hasil survey terhadap 10 koperasi di Bandarlampung menunjukkan kesenjangan antara harapan dan kenyataan. Melalui analisis proses bisnis dengan pendekatan Fishbone dapat ditarik kesimpulan faktor-faktor penyebab kesenjangan implementasi sistem. Faktor hardware, software, brainware, infrastruktur, data dan informasi serta kelembagaan. Dari enam faktor diidentifikasi akar masalah terdapat pada (habit), kebutuhan (need), keberlanjutan (sustainable) dan koordinasi.

\section{DAFTAR PUSTAKA}

[1] User Manual e-KoperasiKementerian Koperasi dan UKM Republik Indonesia. (http://ekoperasi.co.id/download/handbook.pdf, diakses tanggal 28 Mei 2016)

[2] Data Koperasi berdasarkan Propinsi 2006-2014. BPS. [MS. Excel] (https://www.bps.go.id/linkTabelStatis/excel/id/131 $\underline{4}$, diakses tanggal 30 Mei 2016)

[3] Gaspers, V. 2002. Total Quality Management, Cetakan Kedua, Gramedia Pustaka Utama, Jakarta.

[4] Rooney, J.J, Heuvel, L.N, 2004. Root Cause Analysis for beginners, [pdf], (https://servicelink.pinnacol.com/pinnacol_docs/lp/ cdrom_web/safety/management/accident_investigat ion/Root_Cause.pdf, diakses 28 Mei 2016). 